\title{
Nitrogen-fixing and cellulose-producing Gluconacetobacter kombuchae sp. nov., isolated from Kombucha tea
}

\author{
Correspondence \\ Ratan Gachhui \\ ratangachhui@yahoo.com
}

\section{Debasree Dutta and Ratan Gachhui}

\author{
Department of Life Science \& Biotechnology, Jadavpur University, Kolkata 700032, West \\ Bengal, India
}

\begin{abstract}
A few members of the family Acetobacteraceae are cellulose-producers, while only six members fix nitrogen. Bacterial strain $\mathrm{RG}^{\top}{ }^{\top}$, isolated from Kombucha tea, displays both of these characteristics. A high bootstrap value in the 16S rRNA gene sequence-based phylogenetic analysis supported the position of this strain within the genus Gluconacetobacter, with Gluconacetobacter hansenii LMG $1527^{\top}$ as its nearest neighbour ( $99.1 \%$ sequence similarity). It could utilize ethanol, fructose, arabinose, glycerol, sorbitol and mannitol, but not galactose or xylose, as sole sources of carbon. Single amino acids such as L-alanine, L-cysteine and L-threonine served as carbon and nitrogen sources for growth of strain $R G 3^{\top}$. Strain $R G 3^{\top}$ produced cellulose in both nitrogen-free broth and enriched medium. The ubiquinone present was $\mathrm{Q}-10$ and the DNA base composition was $55.8 \mathrm{~mol} \% \mathrm{G}+\mathrm{C}$. It exhibited low values of 5.2-27.77\% DNA-DNA relatedness to the type strains of related gluconacetobacters, which placed it within a separate taxon, for which the name Gluconacetobacter kombuchae sp. nov. is proposed, with the type strain RG3 $^{\top}$ (= LMG $23726^{\top}=$ MTCC $6913^{\top}$ ).
\end{abstract}

Endophytic bacteria colonize the internal tissues of the host plant for mutual benefit. The nitrogen-fixing endophyte Gluconacetobacter diazotrophicus was found to be associated with sugar cane, pineapple, Cameroon grass, sweet potato, mango and banana (Muthukumarasamy et al., 2002), while Gluconacetobacter azotocaptans and Gluconacetobacter johannae inhabit coffee plants (Fuentes-Ramírez et al., 2001); these organisms might provide host plants with useful fixed nitrogen and growth stimulants (Lee et al., 2000; Muthukumarasamy et al., 2002). Based on the strikingly similar high-sugar and low-pH environments presented by the habitats of sugar cane and Kombucha tea (Blanc, 1996), we explored the bacterial flora of Kombucha tea and isolated a nitrogen-fixing strain, Acetobacter nitrogenifigens $\mathrm{RG}^{\mathrm{T}}$ (Dutta \& Gachhui, 2006), and another nitrogen-fixing and cellulose-producing strain, $\mathrm{RG} 3^{\mathrm{T}}$, belonging to the family Acetobacteraceae.

The family Acetobacteraceae has been divided into 10 genera: Acetobacter, Gluconacetobacter, Gluconobacter, Acidomonas (Yamada et al., 1997), Asaia (Yamada et al., 2000), Kozakia (Lisdiyanti et al., 2002), Saccharibacter (Jojima et al., 2004), Swaminathania (Loganathan \& Nair, 2004), Neoasaia (Yukphan et al., 2005) and Granulibacter (Greenberg et al., 2006). Only six members of the family, G. diazotrophicus

The GenBank/EMBL/DDBJ accession numbers for the 16S rRNA and nifH gene sequences of strain $R G 3^{\top}$ are respectively $A Y 688433$ and DQ141200.
(Gillis et al., 1989), G. johannae (Fuentes-Ramírez et al., 2001), G. azotocaptans (Fuentes-Ramírez et al., 2001), Acetobacter peroxydans (Muthukumarasamy et al., 2005), Swaminathania salitolerans (Loganathan \& Nair, 2004) and Acetobacter nitrogenifigens (Dutta \& Gachhui, 2006), are known to fix nitrogen. The genus Gluconacetobacter comprises 15 species with validly published names at present, differentiated on the basis of DNA-DNA relatedness, phylogenetic relationships and morphological characteristics. Isolation of strain $\mathrm{RG} 3^{\mathrm{T}}$ from Kombucha tea is the first instance of a strain within the family having both nitrogen-fixing and cellulose-producing activity. We present morphological, biochemical and genetic evidence that indicates that $R G 3^{\mathrm{T}}$ represents a novel nitrogen-fixing species within the genus Gluconacetobacter.

Kombucha tea is a fermented tea that contains an association of yeast and bacteria. A jelly-like membrane floats in the nutrient solution of tea and sugar exposed to oxygen. At the right temperature, it multiplies continuously. It first spreads over the entire surface of the tea, and then thickens. Kombucha tea was subcultured every 7-10 days by mixing $10 \%$ of old soup with $10 \%$ sucrose dissolved in brewed black tea. After teasing the mat apart in the soup, aliquots of Kombucha mat suspension were spread on LGI agar plates $\left(0.06 \% \mathrm{KH}_{2} \mathrm{PO}_{4}, 0.02 \% \mathrm{~K}_{2} \mathrm{HPO}_{4}, 0.02 \%\right.$ $\mathrm{MgSO}_{4}, 0.002 \% \mathrm{CaCl}_{2}, 0.001 \% \mathrm{FeCl}_{3}, 0.0002 \% \mathrm{Na}_{2} \mathrm{MoO}_{4}$, $10 \%$ sucrose, $\mathrm{pH} 4.5$; Cavalcante \& Döbereiner, 1988) containing $150 \mathrm{mg}$ cycloheximide $\mathrm{l}^{-1}$ (Jimenez-Salgado 
et al., 1997) and $150 \mathrm{mg}$ nystatin $\mathrm{l}^{-1}$. Plates were incubated at $30^{\circ} \mathrm{C}$ for 5 days. Repeated streaking on LGI plates, which contain no combined nitrogen, purified the bacterial isolate. Gas-tight vials of LGI medium inoculated with bacteria (under a microaerophilic environment, without shaking) were assayed for acetylene reduction activity (Stal, 1988). Nitrogenase-positive isolates were selected for further characterization. Strain $\mathrm{RG}^{\mathrm{T}}$, a nitrogen-fixing bacterial strain that exhibited cellulose-producing ability even in nitrogen-free LGI broth, was isolated.

Strain RG $3^{\mathrm{T}}$ produced cellulose when grown in HS medium (Hestrin \& Schramm, 1954) under stationary as well as shaking culture conditions at $30^{\circ} \mathrm{C}$ after incubation for 3 days. The cellulosic character of the pellicle was confirmed by boiling the pellicles with a dilute $\mathrm{NaOH}$ solution (Forng et al., 1989; Navarro \& Komagata, 1999). The polymer was a simple carbohydrate in nature, as indicated by the greenishblue colour of the supernatant with $o$-toluidine. In acidhydrolysed bacterial pellicle samples, the amount of reducing sugars released was found to be comparable to the amount of glucose residues estimated by using glucose oxidase. Thus, the pellicle had repetitive glucose units. Liberation of glucose units upon enzymic digestion of the pellicle with cellulase confirmed it to be composed of cellulose.

Reference strains (Gluconacetobacter hansenii JCM $11196^{\mathrm{T}}$, a gift of Y. Nakagawa and Y. Yamada, Gluconacetobacter intermedius LMG $18909^{\mathrm{T}}$, Gluconacetobacter europeaus LMG $1518^{\mathrm{T}}$, Gluconacetobacter oboediens LMG $18849^{\mathrm{T}}$ and Gluconacetobacter swingsii LMG $22125^{\mathrm{T}}$, from the BCCM/ LMG, and Gluconacetobacter xylinus JCM $7644^{\mathrm{T}}$ from the JCM) were grown in different media according to the instructions of the culture collections. Colony morphology was examined on LGI agar plates and on potato agar plates containing $10 \%$ sucrose. Various phenotypic and morphological characters were tested using standard techniques described previously (Franke et al., 1999; Schüller et al., 2000; Dellaglio et al., 2005; Fuentes-Ramírez et al., 2001). Isoprenoid quinones of the isolate were extracted with chloroform/methanol $(2: 1, \mathrm{v} / \mathrm{v})$ and purified by TLC on silica gel $60 \mathrm{~F}_{254}$ plates $(20 \times 20 \mathrm{~cm}$; Merck $)$ by using benzene as the developing solvent. Quinones recovered from the TLC plates were dissolved in acetone and analysed by HPLC (Lu et al., 1999). The HPLC system was equipped with a reversed-phase column [Luna 5U C18 (2) 100A, $250 \times 4.6 \mathrm{~mm}$; Phenomenex] and a mixture of methanol and isopropanol $(2: 1, \mathrm{v} / \mathrm{v})$ was used as the mobile phase at a flow rate of $1 \mathrm{ml} \mathrm{min}{ }^{-1}$. Types of quinone were identified by absorption at $275 \mathrm{~nm}$ and compared with coenzyme Q-9 and coenzyme Q-10 standards from Sigma-Aldrich. Ubiquinone Q-10 was present in strain $\mathrm{RG}^{\mathrm{T}}$, in agreement with previous observations of the presence of this ubiquinone type in the genus Gluconacetobacter (Cleenwerck et al., 2002).

A 1442 bp fragment of the $16 \mathrm{~S}$ rRNA gene was amplified by PCR with bacteria-specific primers fD1 and rD1 (Weisburg et al., 1991) using Taq polymerase and genomic DNA from $R G 3^{T}$ as the template. The nucleotide sequence showed the following levels of similarity to sequences from strains of the genus Gluconacetobacter after performing similarity searches with FASTA (ungapped): $99.1 \%$ with $G$. hansenii LMG $1527^{\mathrm{T}}, 99.0 \%$ with G. entanii LTH $4560^{\mathrm{T}}, 98.6 \%$ with $G$. rhaeticus DST GL02 ${ }^{\mathrm{T}}, 98.5 \%$ with G. swingsii DST GL01 ${ }^{\mathrm{T}}$, $98.3 \%$ with G. xylinus JCM $7644^{\mathrm{T}}$ and G. europeaus JK2, $98.2 \%$ with $G$. saccharivorans LMG $1582^{\mathrm{T}}$, $98.1 \%$ with $G$. oboediens LTH $2460^{\mathrm{T}}$, G. intermedius $\mathrm{TF}^{\mathrm{T}}$ and G. nataicola LMG $1536^{\mathrm{T}}, 96.7 \%$ with $G$. diazotrophicus LMG $7603^{\mathrm{T}}$, $96.6 \%$ with G. azotocaptans CFN-Ca54 ${ }^{\mathrm{T}}, 96.5 \%$ with $G$. johannae CFN-Cf55 $5^{\mathrm{T}}$ and G. liquefaciens LMG $1382^{\mathrm{T}}$ and $96.4 \%$ with G. sacchari IF 2-6. The phylogenetic tree was deduced using MEGA version 3.1 (Kumar et al., 2004) software after multiple alignment with 16S rRNA gene sequences of other acetic acid bacteria with CLUSTAL W (Thompson et al., 1994). Distances (distance options according to the Kimura two-parameter model) and clustering with the neighbour-joining method were determined by using bootstrap values (Felsenstein, 1985) based on 100 replications. As evident from the tree (Fig. 1), the species of this genus are subgrouped phylogenetically into two clusters, comprising nitrogen-fixers such as $G$. diazotrophicus and cellulose-producers such as G. xylinus, G. swingsii, G. rhaeticus and G. nataicola. The novel strain $\mathrm{RG}^{\mathrm{T}}$, which exhibits both these characteristics, clustered with the 'cellulose-producing' group, along the subbranch formed by $G$. hansenii and G. entanii.

Strain $R G 3^{T}$ differed biochemically from the phylogenetically closely related species of the genus Gluconacetobacter (Table 1). It could be differentiated from G. hansenii and G. entanii, its phylogenetically closest neighbours, in utilizing sorbitol as a sole source of carbon. Additionally, RG3 ${ }^{\mathrm{T}}$ could be differentiated from $G$. hansenii by the non-utilization of ethanol, mannitol and sucrose as carbon sources and from G. entanii by growth in the absence of acetic acid and utilization of D-mannitol as a carbon source. The major difference between $R G 3^{\mathrm{T}}$ and the related 'cellulose-producing' gluconacetobacters is the absence of nitrogen-fixing behaviour in the remaining species. Of the genes responsible for nitrogen fixation, the structural genes nifHDK of the nitrogenase enzyme complex are the most important. A 536 bp region encoding dinitrogenase reductase, nif $H$, was amplified from $\mathrm{RG}^{\mathrm{T}}$ using degenerate primers $19 \mathrm{~F}$ and 407R (Franke et al., 1998) and sequenced, confirming the presence of the nifH gene in $\mathrm{RG} 3^{\mathrm{T}}$.

To determine the genomic relatedness of the new isolate, dot-blot hybridization experiments were carried out with DIG-labelled DNA as described previously (Labrenz et al., 2000) using the detection kit from Roche Applied Sciences following the manufacturer's instructions. Colorimetric quantification of dot intensities was done using the Molecular Analyst software (Bio-Rad) by determining mean pixel densities in circles of equal size. The genomic DNA probe was prepared from strain $\mathrm{RG}^{\mathrm{T}}$; digested with 


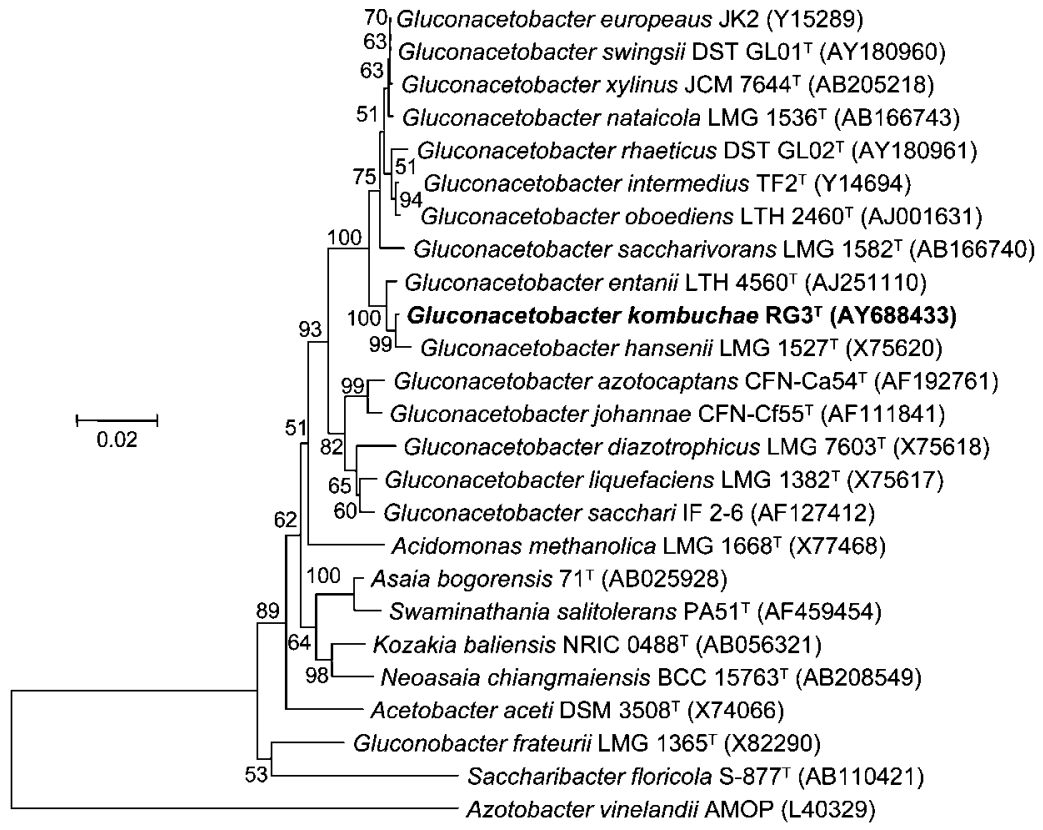

Fig. 1. Phylogenetic relationships based on 16S rRNA gene sequences of acetic acid bacteria including strain $R G 3^{\top}$ and related members of the family Acetobacteraceae. Numerals at nodes indicate bootstrap values derived from 100 replications. GenBank accession numbers are indicated in parentheses. Bar, 2 substitutions per 100 nucleotides.
EcoRI and separated on a $0.7 \%$ agarose gel. Total DNA digests were transferred from gels to nylon membrane by Southern blotting. Hybridization was performed at $75^{\circ} \mathrm{C}$ for $16 \mathrm{~h}$ and the membrane was washed under high-stringency conditions (twice with $2 \times \mathrm{SSC} / 0.1 \%$ SDS at room temperature for $10 \mathrm{~min}$, once with $0.1 \times \mathrm{SSC} / 0.1 \% \mathrm{SDS}$ at $75^{\circ} \mathrm{C}$ for $15 \mathrm{~min}$ ). Low levels of genomic DNA relatedness (DNA-DNA hybridization values of less than $30 \%$ ) were

Table 1. Differential characteristics between strain $R G 3^{\top}$ and closely related species of the genus Gluconacetobacter

Strains/species: 1, strain $\mathrm{RG}^{\mathrm{T}}$ (data from this study); 2, G. hansenii (data from Gosselé et al., 1983; Navarro et al., 1999); 3, G. intermedius LMG $18909^{\mathrm{T}}$ (Boesch et al., 1998); 4, G. europeaus; 5, G. oboediens LMG 18849 ${ }^{\mathrm{T}}$; 6, G. xylinus (data in columns 4-6 from Sokollek et al., 1998); 7, G. swingsii LMG 22125 (Dellaglio et al., 2005); 8, G. entanii LTH 4560 ${ }^{\mathrm{T}}$ (Schüller et al., 2000); 9, G. rhaeticus LMG 22126 ${ }^{\mathrm{T}}$ (Dellaglio et al., 2005); 10, G. nataicola LMG 1536 ${ }^{\mathrm{T}}$; 11, G. saccharivorans LMG $1582^{\mathrm{T}}$ (data in columns 10 and 11 from Lisdiyanti et al., 2006). +, Positive; -, negative; W, weak; V, variable; ND, not determined; NR, not reported.

\begin{tabular}{|c|c|c|c|c|c|c|c|c|c|c|c|}
\hline Characteristic & 1 & 2 & 3 & 4 & 5 & 6 & 7 & 8 & 9 & 10 & 11 \\
\hline 2-Keto-D-gluconate & - & + & - & NR & + & + & + & - & + & + & + \\
\hline Growth without acetic acid & + & + & + & - & + & + & + & - & + & + & + \\
\hline $\begin{array}{l}\text { Growth on } 3 \% \text { ethanol in the presence } \\
\text { of } 4-8 \% \text { acetic acid }\end{array}$ & - & - & NR & + & + & - & + & + & + & - & - \\
\hline Ethanol & + & - & NR & - & - & - & + & NR & + & - & - \\
\hline D-Xylose & - & V & NR & + & - & + & + & NR & + & NR & NR \\
\hline D-Fructose & + & V & NR & + & + & + & + & + & + & NR & NR \\
\hline Maltose & + & V & NR & + & + & + & + & + & + & NR & NR \\
\hline Sucrose & + & - & NR & - & + & + & + & + & + & NR & NR \\
\hline Growth and pellicle formation in LGI medium & + & - & - & - & - & - & - & ND & ND & ND & ND \\
\hline Cellulose production & + & $\mathrm{V}$ & + & $\mathrm{V}$ & - & + & + & - & + & + & - \\
\hline DNA G $+\mathrm{C}$ content $(\mathrm{mol} \%)$ & 55.8 & $58-63$ & NR & $56-58$ & 59.9 & $55-63$ & 61.7 & 58 & 63.4 & 62 & 61 \\
\hline
\end{tabular}


observed between strain $\mathrm{RG}^{\mathrm{T}}$ and its phylogenetically closest relatives; DNA-DNA relatedness values of $24.8 \%$ (with G. hansenii JCM $7643^{\mathrm{T}}$ ), $21.8 \%$ (G. swingsii LMG $\left.22125^{\mathrm{T}}\right), 27.7 \%$ (G. xylinus JCM $\left.7644^{\mathrm{T}}\right), 24.6 \%$ (G. europeaus LMG $1518^{\mathrm{T}}$ ), $5.2 \%$ (G. oboediens LMG $18849^{\mathrm{T}}$ ) and $23.4 \%$ (G. intermedius LMG $18909^{\mathrm{T}}$ ) were obtained.

The limitations of $16 \mathrm{~S}$ rRNA gene sequencing for the differentiation of closely related species have been documented (Fox et al., 1992), but a DNA-DNA reassociation level below $70 \%$ indicates a distinct species (Stackebrandt \& Goebel, 1994). Although the 16S rRNA gene sequence similarity levels were greater than $97 \%$, low levels (below $30 \%$ ) of DNA relatedness were found among the closely related Gluconacetobacter species studied. In view of the low physiological, biochemical, phylogenetic and genetic similarities among members of the genus Gluconacetobacter, we recommend that strain $R G 3^{\mathrm{T}}$ should be assigned to a novel species of the genus Gluconacetobacter. We propose the name Gluconacetobacter kombuchae sp. nov. for strain RG3 ${ }^{\mathrm{T}}$ isolated from Kombucha tea.

\section{Description of Gluconacetobacter kombuchae sp. nov.}

Gluconacetobacter kombuchae (kom.bu' chae. N.L. gen. fem. n. kombuchae from Kombucha, a kind of fermented tea).

Cells are straight rods, approximately $2.0-3.0 \mu \mathrm{m}$ long and $0.1-0.2 \mu \mathrm{m}$ wide, and occur singly or in bunches. Gramnegative, motile with polar flagellation, catalase-positive and oxidase-negative. Growth occurs on nitrogen-free LGI plates at 30 and $37^{\circ} \mathrm{C}$ and in LGI broth under microaerophilic conditions with formation of a cellulosic pellicle on the surface. Colonies grown on LGI plates are smooth, round, dull, dry, white and opaque, $0.5-1.0 \mathrm{~mm}$ in diameter after incubation for 5 days. Dark-yellow colonies are formed on LGI agar supplemented with $0.001 \%$ bromothymol blue. Colonies on potato agar are light brown after 5 days of incubation, but the intensity increases after 10 days. The type strain is aerobic and fixes atmospheric nitrogen microaerobically. It oxidizes ethanol to acetic acid, turning EYC or GYC opaque plates transparent, and overoxidizes acetate and lactate to $\mathrm{CO}_{2}$ and water. L-Alanine supports growth, as well as the formation of a pellicle, as the sole source of carbon and nitrogen in LGI broth. Can utilize the single amino acids L-cysteine and L-threonine as sole sources of carbon and nitrogen but not L-phenylalanine. Butanol $(0.1 \%)$ can not support growth in nitrogen-free medium. In the absence of yeast extract, the type strain can utilize different carbon sources such as D-arabinose, D-mannitol, D-sorbitol and glycerol, but not D-galactose or D-xylose, and can grow on $30 \%$ sucrose and $30 \%$ glucose. Formation of a cellulosic pellicle is prevalent in the presence of almost all the general carbon sources used except sorbitol and gluconate. Can not utilize D-cellobiose, maltose or lactose in LGI medium for growth. The ubiquinone present is of the type Q-10 and the DNA G + C content of the type strain is $55.8 \mathrm{~mol} \%$.
The type strain is strain $\mathrm{RG}^{\mathrm{T}}\left(=\mathrm{LMG} 23726^{\mathrm{T}}=\mathrm{MTCC}\right.$ $\left.6913^{\mathrm{T}}\right)$, isolated from Kombucha tea.

\section{Acknowledgements}

We thank Dr Yasuyoshi Nakagawa and Dr Yuzo Yamada for promptly sending us G. hansenii JCM $1527^{\mathrm{T}}$ as a gift. This work was partially supported from funding agencies of the Government of India: CSIR (no. 38/1097/04/EMR-II) and DBT (no. BT/PR5111/BCE/08/340/ 2004). Financial support was also received by D. D. and R. G. from Jadavpur University.

\section{References}

Blanc, P. J. (1996). Characterization of the tea fungus metabolites. Biotechnol Lett 18, 139-142.

Boesch, C., Trček, J., Sievers, M. \& Teuber, M. (1998). Acetobacter intermedius sp. nov. Syst Appl Microbiol 21, 220-229.

Cavalcante, V. \& Döbereiner, J. (1988). A new acid tolerant nitrogen-fixing bacterium associated with the sugarcane. Plant Soil 108, 23-31.

Cleenwerck, I., Vandemeulebroecke, K., Janssens, D. \& Swings, J. (2002). Re-examination of the genus Acetobacter, with descriptions of Acetobacter cerevisiae sp. nov. and Acetobacter malorum sp. nov. Int J Syst Evol Microbiol 52, 1551-1558.

Dellaglio, F., Cleenwerck, I., Felis, G. E., Engelbeen, K., Janssens, D. \& Marzotto, M. (2005). Description of Gluconacetobacter swingsii sp. nov. and Gluconacetobacter rhaeticus sp. nov., isolated from Italian apple fruit. Int J Syst Evol Microbiol 55, 2365-2370.

Dutta, D. \& Gachhui, R. (2006). Novel nitrogen-fixing Acetobacter nitrogenifigens sp. nov., isolated from Kombucha tea. Int J Syst Evol Microbiol 56, 1899-1903.

Felsenstein, J. (1985). Confidence limits on phylogenies: an approach using the bootstrap. Evolution 39, 783-791.

Forng, E. R., Anderson, S. M. \& Cannon, R. E. (1989). Synthetic medium for Acetobacter xylinum that can be used for isolation of auxotrophic mutants and study of cellulose biosynthesis. Appl Environ Microbiol 55, 1317-1319.

Fox, G. E., Wisotzkey, J. D. \& Jurtshuk, P., Jr (1992). How close is close: $16 \mathrm{~S}$ rRNA sequence identity may not be sufficient to guarantee species identity. Int J Syst Bacteriol 42, 166-170.

Franke, I. H., Fegan, M., Hayward, A. C. \& Sly, L. I. (1998). Nucleotide sequence of the nifH gene coding for nitrogen reductase in the acetic acid bacterium Acetobacter diazotrophicus. Lett Appl Microbiol 26, 12-16.

Franke, I. H., Fegan, M., Hayward, A. C., Leonard, G., Stackebrandt, E. \& Sly, L. I. (1999). Description of Gluconacetobacter sacchari sp. nov., a new species of acetic acid bacterium isolated from the leaf sheath of sugar cane and from the pink sugar-cane mealy bug. Int J Syst Bacteriol 49, 1681-1693.

Fuentes-Ramirez, L. E., Bustillos-Cristales, R., Tapia-Herńandez, A., Jiménez-Salgado, T., Wang, E. T., Martínez-Romero, E. \& Caballero-Mellado, J. (2001). Novel nitrogen-fixing acetic acid bacteria, Gluconacetobacter johannae sp. nov. and Gluconacetobacter azotocaptans sp. nov., associated with coffee plants. Int J Syst Evol Microbiol 51, 1305-1314.

Gillis, M., Kersters, K., Hoste, B., Janssens, D., Kroppenstedt, R. M., Stephan, M. P., Teixeria, K. R. S., Döbereiner, J. \& De Ley, J. (1989). Acetobacter diazotrophicus sp. nov., a nitrogen-fixing acetic bacterium associated with sugarcane. Int J Syst Bacteriol 39, 361-364. 
Gosselé, F., Swings, J., Kesters, K., Pauwels, P. \& De Ley, J. (1983). Numerical analysis of phenotypic features and protein gel electropherograms of a wide variety of Acetobacter strains. Proposal for the improvement of the taxonomy of the genus Acetobacter Beijerinck 1898. Syst Appl Microbiol 4, 338-368.

Greenberg, D. E., Porcella, S. F., Stock, F., Wong, A., Conville, P. S., Murray, P. R., Holland, S. M. \& Zelazny, A. M. (2006). Granulibacter bethesdensis gen. nov., sp. nov., a distinctive pathogenic acetic acid bacterium in the family Acetobacteraceae. Int J Syst Evol Microbiol 56, 2609-2616.

Hestrin, S. \& Schramm, M. (1954). Synthesis of cellulose by Acetobacter xylinum. Biochem J 58, 345-352.

Jimenez-Salgado, T., Fuentes-Ramírez, L. E., Tapia-Hernandez, A., Mascarúa-Esparza, M. A., Martínez-Romero, E. \& CaballeroMellado, J. (1997). Coffea arabica L., a new host plant for Acetobacter diazotrophicus, and isolation of other nitrogen-fixing acetobacteria. Appl Environ Microbiol 63, 3676-3683.

Jojima, Y., Mihara, Y., Suzuki, S., Yokozeki, K., Yamanaka, S. \& Fudou, R. (2004). Saccharibacter floricola gen. nov., sp. nov., a novel osmophilic acetic acid bacterium isolated from pollen. Int J Syst Evol Microbiol 54, 2263-2267.

Kumar, S., Tamura, K. \& Nei, M. (2004). MEGA3: integrated software for molecular evolutionary genetics analysis and sequence alignment. Brief Bioinform 5, 150-163.

Labrenz, M., Tindall, B. J., Lawson, P. A., Collins, M. D., Schumann, P. \& Hirsch, P. (2000). Staleya guttiformis gen. nov., sp. nov., and Sulfitobacter brevis sp. nov., $\alpha$-3-Proteobacteria from hypersaline, heliothermal and meromictic Antarctic Ekho Lake. Int J Syst Evol Microbiol 50, 303-313.

Lee, S., Sevilla, M., Meletzus, D., Gunapala, N. \& Kennedy, C. (2000). Characterization of nitrogen fixation genes and plant-growth promoting properties in Acetobacter diazotrophicus, an endophyte of sugarcane. In Plant-Microbe Interactions, vol. 5, pp. 196-204. Edited by G. Stacey \& N. T. Keen. St Paul, MN: American Phytopathological Society.

Lisdiyanti, P., Kawasaki, H., Widyastuti, Y., Saono, S., Seki, T., Yamada, Y., Uchimura, T. \& Komagata, K. (2002). Kozakia baliensis gen. nov., sp. nov., a novel acetic acid bacterium in the $\alpha$ Proteobacteria. Int J Syst Evol Microbiol 52, 813-818.

Lisdiyanti, P., Navarro, R. R., Uchimura, T. \& Komagata, K. (2006). Reclassification of Gluconacetobacter hansenii strains and proposals of Gluconacetobacter saccharivorans sp. nov. and Gluconacetobacter nataicola sp. nov. Int J Syst Evol Microbiol 56, 2101-2111.

Loganathan, P. \& Nair, S. (2004). Swaminathania salitolerans gen. nov., sp. nov., a salt-tolerant, nitrogen-fixing and phosphatesolubilizing bacterium from wild rice (Porteresia coarctata Tateoka). Int J Syst Evol Microbiol 54, 1185-1190.

Lu, S.-F., Lee, F.-L. \& Chen, H.-K. (1999). A thermotolerant and high acetic-acid producing bacterium Acetobacter sp. 114-2. J Appl Microbiol 86, 55-62.
Muthukumarasamy, R., Revathi, G., Seshadri, S. \& Lakshminarsimhan, C. (2002). Gluconacetobacter diazotrophicus (syn. Acetobacter diazotrophicus), a promising diazotrophic endophyte in tropics. Curr Sci 83, 137-145.

Muthukumarasamy, R., Cleenwerck, I., Revathi, G., Vadivelu, M., Janssens, D., Hoste, B., Gum, K. U., Park, K. D., Son, C. Y. \& other authors (2005). Natural association of Gluconacetobacter diazotrophicus and diazotrophic Acetobacter peroxydans with wetland rice. Syst Appl Microbiol 28, 277-286.

Navarro, R. R. \& Komagata, K. (1999). Differentiation of Gluconacetobacter liquefaciens and Gluconacetobacter xylinus on the basis of DNA base composition, DNA relatedness, and oxidation products from glucose. J Gen Appl Microbiol 45, 7-15.

Navarro, R. R., Uchimura, T. \& Komagata, K. (1999). Taxonomic heterogeneity of strains comprising Gluconacetobacter hansenii. J Gen Appl Microbiol 45, 295-300.

Schüller, G., Hertel, C. \& Hammes, W. P. (2000). Gluconacetobacter entanii sp. nov., isolated from submerged high-acid industrial vinegar fermentations. Int J Syst Evol Microbiol 50, 2013-2020.

Sokollek, S. J., Hertel, C. \& Hammes, W. P. (1998). Description of Acetobacter oboediens sp. nov. and Acetobacter pomorum sp. nov., two new species isolated from industrial vinegar fermentations. Int J Syst Bacteriol 48, 935-940.

Stackebrandt, E. \& Goebel, B. M. (1994). Taxonomic note: a place for DNA-DNA reassociation and 16S rRNA sequence analysis in the present species definition in bacteriology. Int J Syst Bacteriol 44, 846-849.

Stal, L. J. (1988). Nitrogen fixation in cyanobacterial mats. Methods Enzymol 167, 475-484.

Thompson, J. D., Higgins, D. G. \& Gibson, T. J. (1994). CLUSTAL W: improving the sensitivity of progressive multiple sequence alignment through sequence weighting, position-specific gap penalties and weight matrix choice. Nucleic Acids Res 22, 4673-4680.

Weisburg, W. G., Barns, S. M., Pelletier, D. A. \& Lane, D. J. (1991). $16 \mathrm{~S}$ ribosomal DNA amplification for phylogenetic study. J Bacteriol 173, 697-703.

Yamada, Y., Hoshino, K. \& Ishikawa, T. (1997). The phylogeny of acetic acid bacteria based on the partial sequences of $16 \mathrm{~S}$ ribosomal RNA: the elevation of the subgenus Gluconacetobacter to the generic level. Biosci Biotechnol Biochem 61, 1244-1251.

Yamada, Y., Katsura, K., Kawasaki, H., Widyastuti, Y., Saono, S., Seki, T., Uchimura, T. \& Komagata, K. (2000). Asaia bogorensis gen. nov., sp. nov., an unusual acetic acid bacterium in the $\alpha$ Proteobacteria. Int J Syst Evol Microbiol 50, 823-829.

Yukphan, P., Malimas, T., Potacharoen, W., Tanasupawat, S., Tanticharoen, M. \& Yamada, Y. (2005). Neoasaia chiangmaiensis gen. nov., sp. nov., a novel osmotolerant acetic acid bacterium in the alpha-Proteobacteria. J Gen Appl Microbiol 51, 301-311. 